\title{
The Effect of Electric Spot-Welding on the Mechanical Properties of Different Orthodontic Wire Alloys
}

\author{
Leonard Euler Andrade Gomes Nascimento ${ }^{\mathrm{a}}$, Rogério Lacerda dos Santos ${ }^{\mathrm{b} *}$,
}

Matheus Melo Pithonc, Mônica Tirre de Souza Araújo ${ }^{\text {a }}$

Matilde Gonçalves Nojima ${ }^{\text {a }}$ Lincoln Issamu Nojima

${ }^{\mathrm{a}}$ Department of Orthodontics, Federal University of Rio de Janeiro - UFRJ, Av. Professor Rodolpho Paulo Rocco, 325, Ilha do Fundão, CEP 21941-617, Rio de Janeiro, RJ, Brazil

${ }^{b}$ Department of Orthodontics, Federal University of Campina Grande - UFCG, Av. dos Universitários, s/n, Rod. Patos/Teixeira, Km 1, Santa Cecília, CEP 58700-970, Patos, PB, Brazil ${ }^{\mathrm{c}}$ Centro Odontomédico Dr. Altamirando da Costa Lima, Av. Otávio Santos, 395, Sala 705, Vitória da Conquista, BA, Brazil

Received: September 19, 2011; Revised: February 26, 2012

The aim of this study was to test the hypothesis that there is a direct relationship between surface structure and tensile strength of orthodontic alloys submitted to different levels of welding current. Three types of alloys were assessed. One hundred and eight cross-sectional test specimens ("X") were made, 18 for each wire combination, and divided into 6 groups: SS (steel-steel); SN (steel-NiTi); SB (steel-Beta-Ti); NN (NiTi-NiTi); NB (NiTi-Beta-Ti) and BB (Beta-Ti-Beta-Ti), submitted to 6 spot-welding procedures at different levels of current (Super Micro Ponto 3000). Student-Newman-Keuls, Wilcoxon signed-rank, and Kruskal-Wallis tests were used $(\mathrm{p}<.05)$. Statistical difference was found between SN group and all the other alloy combinations $(p<.05)$. Initial roughness of alloys ranged from .04 to $.55 \mathrm{Ra}$, with statistical difference between groups $(\mathrm{p}<.001)$. The hypothesis was rejected and the tensile strength of Ti-alloys combinations Steel $\times$ Beta-Ti was significantly affected by the current level at P50, which changed the properties and structure of the wires.

Keywords: orthodontic wire, welding, topography, tensile strength

\section{Introduction}

Use of the welding machine for orthodontic purposes dates back to 1934, but resistance to its use and differences in opinion about the benefits of electric welding versus braze welding still persist ${ }^{1}$.

Research has shown that some ions may be released from the weld ${ }^{2-7}$ and this exposure could lead to several side effects causing acute or chronic direct toxic alterations ${ }^{8}$. The "World Health Organization International Agency for Research on Cancer" and "United States National Toxicology Program" consider cadmium, copper, silver and zinc, silver soldering components as being metals that are potentially carcinogenic to human beings ${ }^{8}$. Thus, spot-welding has been indicated as a safe alternative in Orthodontics ${ }^{1}$.

Spot-welding is a process in which two or more surfaces are joined by heat generated by electric current through pieces that are held together under force applied by two electrodes ${ }^{9}$. Clinicians have avoided electric welding due to its low mechanical strength in comparison with silver soldering, and the following disadvantages: difficulty of performing welding, possibility of losing the mechanical properties of the wires, corrosion and low biocompatibility with oral tissues ${ }^{10-11}$. However, spot-welding has the following advantages: fast welding, simplified laboratory work, low cost to the professional and it makes it easy for the patient to perform oral hygiene ${ }^{10}$.

*e-mail: lacerdaorto@hotmail.com
With the advent of new metal alloys, diverse orthodontic wires with properties favoring weldability have become available. Nickel-titanium (NiTi) and Beta-titanium (Beta-Ti) alloys are part of this group and satisfactory clinical welding has been obtained with them ${ }^{12-13}$.

Factors such as the cross-section of wires and metal alloy as well as the type of welding machine, tensile strength, shape of the electrodes, pressure and heat dissipation can influence the mechanical characteristics of union between orthodontic wires ${ }^{14}$

Therefore, the aim of this study was to test the hypothesis that there is a direct relationship between surface structure and tensile strength of orthodontic alloys submitted to spot-welding at different levels of current.

\section{Material and Methods}

\subsection{Sample composition}

One hundred and eight test specimens were fabricated by welding 2 rectangular wire segments, each $6 \mathrm{~cm}$ long, superimposed to form an " $X$ " shape measuring $0.019 " \times 0.025$ ". The stainless steel (Morelli, Sorocaba, São Paulo, Brazil), nickel-titanium (Morelli, Sorocaba, São Paulo, Brazil) and beta-titanium alloys (Morelli, Sorocaba, São Paulo, Brazil) assessed were distributed into 6 groups: 
Group SS (steel - steel); Group SN (steel - NiTi); Group SB (steel - Beta-Ti); Group NN (NiTi - NiTi); Group NB (NiTi - Beta-Ti) and Group BB (Beta-Ti - Beta-Ti). Each group was submitted to 3 spot-welding locations at different levels of current (P): P30 (30 W power); P40 (40 W power) and $\mathrm{P} 50$ (50 W power), totaling 18 combinations. The $50 \mathrm{~W}$ power corresponded to the total current of the spot-welding machine.

Welding was performed by applying one cross-sectional pulse ("X") using the spot-welding machine (SMP- Super Micro Ponto 3000, Kernit, Indaiatuba, Brazil). For each solder performed, the extremities of the electrodes were cleaned with 400 grit water abrasive paper (3M, Sumaré, São Paulo, Brazil).

Test specimen fabrication and soldering were performed by a single operator. Next, the test specimens were submitted to the tensile test in the universal mechanical testing machine (EMIC DL 2.000, São José dos Pinhais, Paraná, Brazil) at speed of $0.5 \mathrm{~mm} / \mathrm{min}$. The samples were submitted to tensile load until rupture occurred (Maximum tensile strength).

Statistical analysis was performed with the Statistical Package for Social Sciences (SPSS Inc., Chicago, IL, USA). Descriptive statistics that included mean and standard deviation were calculated for each of the six groups. The analysis of variance (ANOVA) and Kruskal-Wallis multiple comparisons tests were used at a level of significance of $\mathrm{p}>.05$ to identify differences in tensile strength among the samples of each group.

\subsection{Topography analysis and surface roughness measurements}

The topography of wires was examined by scanning electron microscopy - SEM (JEOL, JSM-6500, Tokyo, Japan). The central area (0.030 inch) of the wires was observed and images of the specimens were obtained from secondary electrons, at $110 \times$ magnification.

The surface roughness of the wire was examined with a rugosimeter (Mitutoyo SJ-201, Aurora, Illinois, EUA). An average roughness was obtained by taking three readouts of standard $\mathrm{Ra}$ of $0.8 \mathrm{~cm}$ in the central area of the rectangular wire surface. Roughness analysis before and after the use of soldering was performed for all 18 wire combination used in this experiment. The distribution of roughness was checked with the Shapiro-Wilk test. Because roughness in the wires before soldering was not distributed normally, the Wilcoxon and Student-Newman-Keuls signed-rank test was used to examine differences in roughness scores before and after soldering. The alpha level was established at $5 \%(\mathrm{p}<.05)$.

\section{Results}

The mean values shown above were needed to cause rupture (Maximum tensile strength) in the welding of alloy wire combinations (Table 1 and Figure 1).

Fracture strength of the SS group at P50 was higher than in the other groups, irrespective of the alloys. The maximum tensile strength values were progressive from P30 to P50, except for the SB and BB groups, which showed higher strength values at $\mathrm{P} 40$.

Statistical difference was found between the SN group and all the other groups at P30, P40 and P50. There was no statistical difference between NN and NB groups at all the levels of current tested $(\mathrm{p}>.05)$.

\subsection{Topography analysis and surface roughness measurements}

Before the welding process, the wires showed homogeneity $(\mathrm{SD}=.02)$ and mean roughness values ranging from .04 to $.55 \mathrm{Ra}$ (Table 2), with statistical difference between them before the welding process $(p<.001)$. After welding, there was a significant increase in the degree of roughness of the wires (Table 2). There was statistical difference between the SS group and the groups $\mathrm{NN}$ and BB at P30, P40 and P50 ( $<<.001)$. After welding there was no statistical difference between groups $\mathrm{NN}$ and BB $(\mathrm{p}>.001)$.

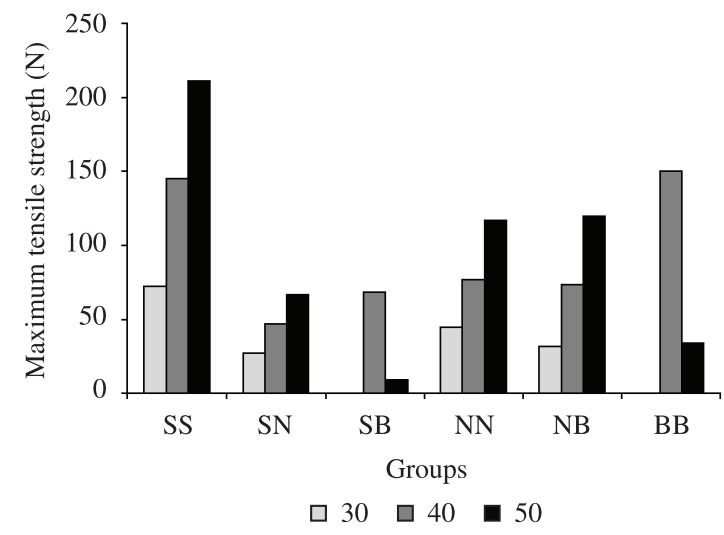

Figure 1. Maximum tensile strength of alloys welded at different levels of current.

Table 1. Analysis of maximum tensile strength of alloys welded at different levels of current.

\begin{tabular}{|c|c|c|c|c|c|c|}
\hline \multirow[t]{2}{*}{ Groups } & \multicolumn{2}{|l|}{ P 30} & \multicolumn{2}{|l|}{ P 40} & \multicolumn{2}{|l|}{ P 50} \\
\hline & $\mathbf{M}(\mathbf{S D})$ & Est & $\mathbf{M}(\mathbf{S D})$ & Est & M (SD) & Est \\
\hline SS & $72.12(17.54)$ & A & $145.0(28.71)$ & $\mathrm{C}$ & $210.7(51.54)$ & $\mathrm{C}$ \\
\hline $\mathrm{SN}$ & $27.0(3.62)$ & $\mathrm{C}$ & $46.64(10.48)$ & B & $66.64(6.46)$ & $\mathrm{B}$ \\
\hline $\mathrm{SB}$ & $58.80(18.52)$ & A & $68.40(12.64)$ & A & $8.82(3.33)$ & $\mathrm{E}$ \\
\hline $\mathrm{NN}$ & $44.29(7.05)$ & B & 76.83 (18.13) & A & $116.62(21.65)$ & A \\
\hline NB & $31.55(18.52)$ & $\mathrm{B}$ & $73.50(12.44)$ & A & $119.56(44.98)$ & A \\
\hline $\mathrm{BB}$ & $78.40(14.50)$ & A & $149.94(58.40)$ & $\mathrm{C}$ & $33.71(16.75)$ & $\mathrm{D}$ \\
\hline
\end{tabular}

$* \mathrm{M}(\mathrm{SD})=$ Mean (standard deviation, $\mathrm{P}=$ (total power of machine in percentage). Analysis submitted to ANOVA and Kruskal-Wallis test (analyze in column). Equal letters = absence of statistically significant difference $(\mathrm{p}>.05)$. Mean: $\mathrm{N}$. 
The roughness assessment showed a higher trend towards topographic alterations, such as melting, as higher levels of current such as P40 and P50 were used, P50 being the most significant (Figure 2). P30 showed minor topographic alterations (Figure 3 ). The stainless steel alloy wires showed low surface melting (Figure 3). On the other hand, the best relationship between topography and maximum tensile strength for the NiTi and Beta-Ti alloy combinations was found at P40 (Figure 4). However, topographic alterations due to melting were present more frequently in the SB and BB groups at $\mathrm{P} 40$, and $\mathrm{SN}$ group at P50.

\section{Discussion}

Most orthodontic materials present some type of interaction with the oral environment, which may compromise their use due to deterioration of their mechanical and physical properties or appearance. One of the degradation processes is corrosion $^{15}$. Corrosion of metals, particularly when it occurs in the mouth, is of the electrolytic type due to the interaction of two alloys causing galvanic corrosion ${ }^{15}$.

One of the fundamental conditions for using metal materials in the oral environment is that they resist the corrosive action of saliva, alkaline and acid foods ${ }^{16-17}$ as well as $\mathrm{pH}$ and temperature variations. One of the materials used in Orthodontics, which is more susceptible to corrosion, is silver soldering ${ }^{18}$. This material is used to join stainless steel alloys or other types of alloys in the fabrication of orthodontic appliances.

In conventional dental brazing - defined as soldering at a temperature of over $450^{\circ} \mathrm{C}$ - the parent metals are joined with different types of metals, which may reduce corrosion resistance because of galvanic corrosion between metals ${ }^{19-20}$. High corrosion rates can influence biocompatibility. Sestini et al. ${ }^{21}$ found that traditional silver solder was toxic for osteoblast differentiation, fibroblast viability and keratinocyte growth.

Table 2. Descriptive Statistics of Surface roughness of alloys welded at different levels of current.

\begin{tabular}{|c|c|c|c|c|c|c|c|c|c|}
\hline \multicolumn{3}{|c|}{ As received } & \multicolumn{7}{|c|}{ After welding } \\
\hline \multirow[t]{2}{*}{ Alloys } & \multirow[b]{2}{*}{ M (SD) } & \multirow[b]{2}{*}{ Est } & \multirow[t]{2}{*}{ Groups } & \multicolumn{2}{|l|}{ P 30} & \multicolumn{2}{|l|}{ P 40} & \multicolumn{2}{|l|}{ P 50} \\
\hline & & & & M (SD) & Est & M (SD) & Est & M (SD) & Est \\
\hline Stainless steel & $0.042(0.020)$ & A & SS & $0.118(0.076)$ & A & $0.642(0.098)$ & A & $1.01(0.106)$ & A \\
\hline NiTi & $0.551(0.029)$ & B & $\mathbf{N N}$ & $0.901(0.101)$ & $\mathrm{B}$ & $1.17(0.120)$ & B & $1.42(0.139)$ & $\mathrm{B}$ \\
\hline Beta-Ti & $0.232(0.021)$ & $\mathrm{C}$ & BB & $0.867(0.109)$ & $\mathrm{B}$ & $1.20(0.132)$ & $\mathrm{B}$ & $1.65(0.151)$ & $\mathrm{B}$ \\
\hline
\end{tabular}

$* \mathrm{M}(\mathrm{SD})=$ Mean (standard deviation, $\mathrm{P}=$ (total power of machine in percentage). Analysis submitted to Wilcoxon and Student-Newman-Keuls test (analyze in column). Equal letters = absence of statistically significant difference $(p>.001)$. Mean: Ra.

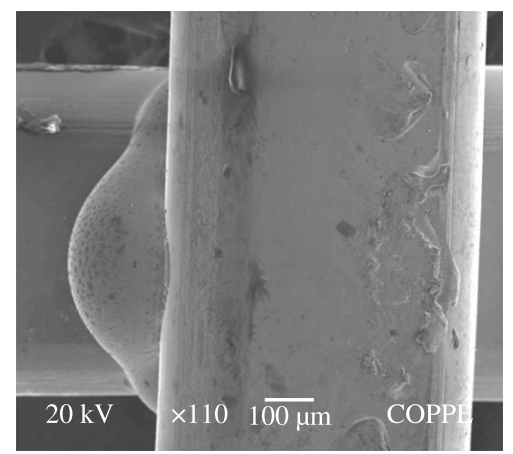

(a)

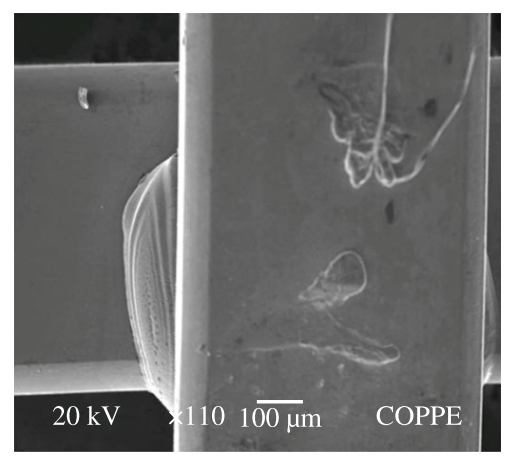

(d)

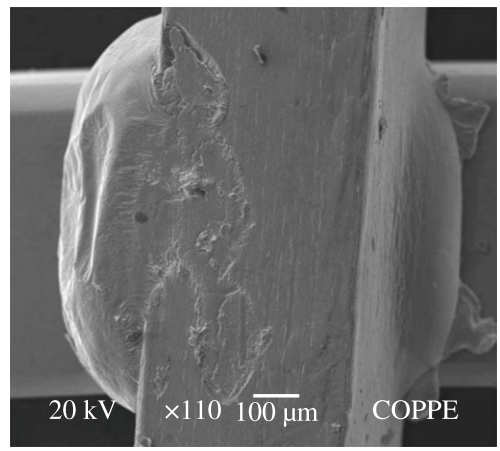

(b)

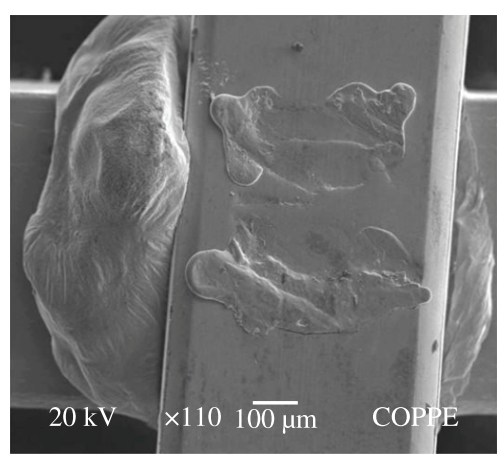

(e)

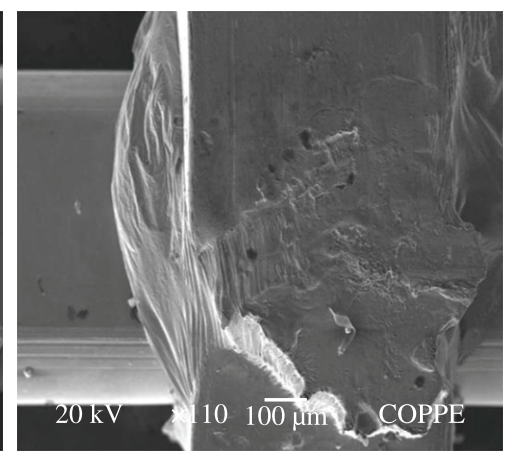

(c)

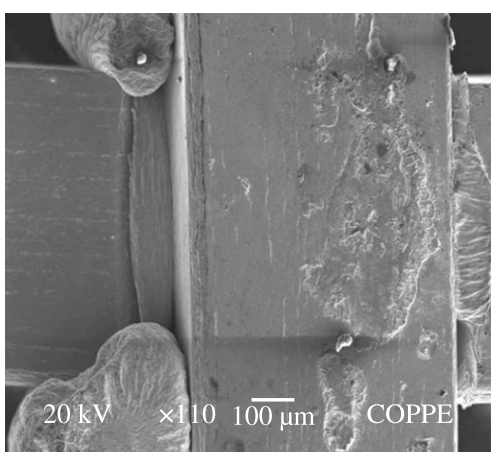

(f)

Figure 2. Topography under SEM of alloy combinations at P50: a) SS $\times$ SS, b) SS $\times$ NiTi, c) $\mathrm{SS} \times$ Beta-Ti, d) NiTi $\times$ NiTi, e) NiTi $\times$ Beta-Ti and f) Beta-Ti $\times$ Beta-Ti. 


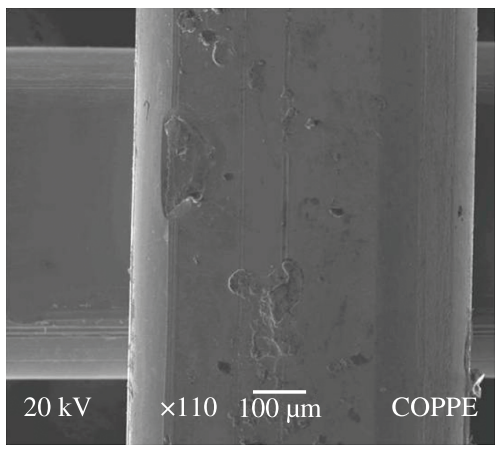

(a)

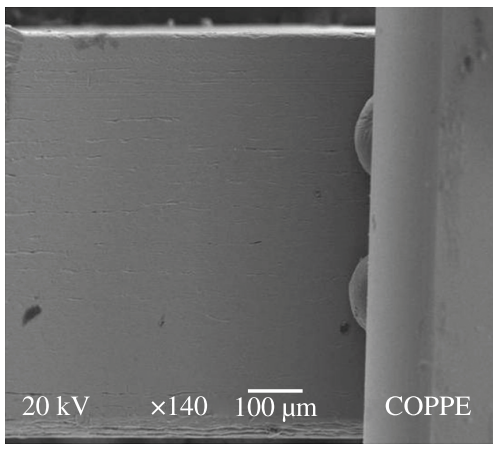

(b)

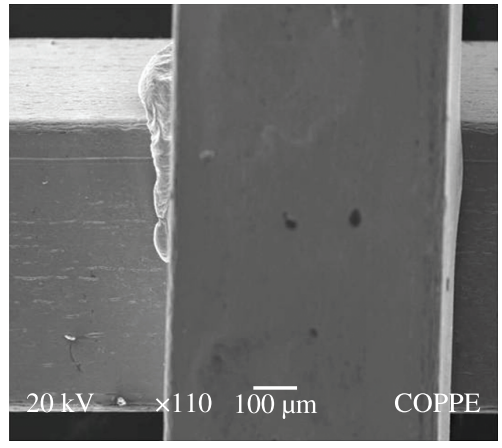

(c)

Figure 3. Topography under SEM of alloy combinations at P30: a) SS $\times$ SS, b) SS $\times$ Beta-Ti and c) Beta-Ti $\times$ Beta-Ti.

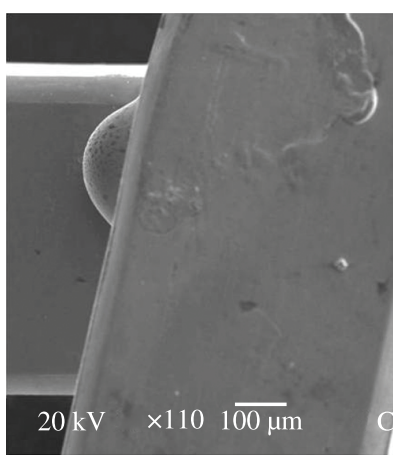

(a)
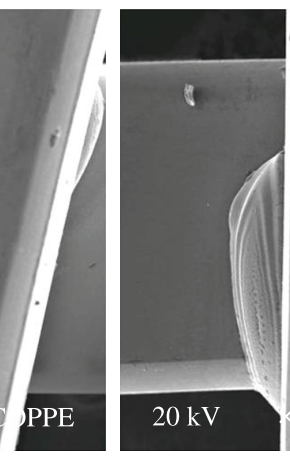

$20 \mathrm{kV}$

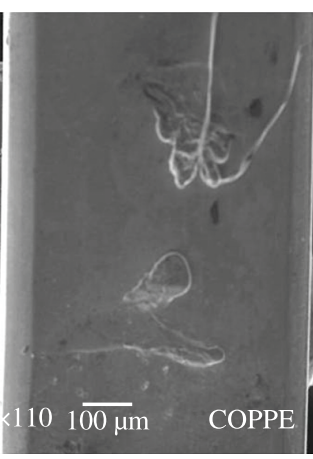

(b)

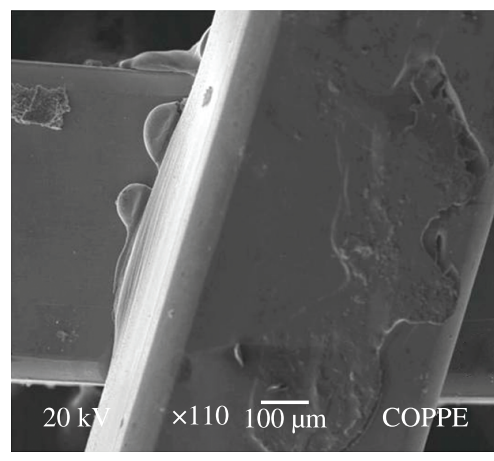

(c)

Figure 4. Topography under SEM of alloy combinations at P40: a) SS $\times \mathrm{NiTi}$, b) NiTi $\times$ NiTi and c) $\mathrm{NiTi} \times$ Beta-Ti.

Contrary to routine orthodontic practice, results suggest that silver soldering must be used with caution in the oral environment ${ }^{22-23}$, which is why this type of welding has been discouraged.

Based on this premise, other types of solders ${ }^{3-4}$ free of the metal ions released from silver soldering, such as the electric spot-welding ${ }^{2-7}$ and laser welding, ${ }^{20-21,24-26}$ have been used.

However, laser welding is still little used in the orthodontic clinic. Different combinations of orthodontic wires can change the penetration depth of laser into the metals and affect the joint strength of the laser welded $\operatorname{part}^{24-25}$, which can affect the mechanical strength of the laser weld $^{19,24-26}$. On the other hand, electric spot-welding has been used in orthodontics and has shown few effects of heat on the area surrounding the site to be welded, in comparison with conventional dental brazing (at temperatures over $\left.450^{\circ}\right)^{27}$. Thus, this study focused on the use of electric spot-welding at different levels of current.

The results of this study demonstrated that the Steel $\times$ Steel combination showed better performance, and higher tensile strength was needed to cause rupture ${ }^{22}$ in comparison with the other alloy combinations. The alloys submitted to welding in electric machines at P50 showed heat intolerance with significant changes in roughness ${ }^{23}$ over a large area of fusion and porosity ${ }^{28}$ in the welding area, which suggests a significant rearrangement in the molecular structure of alloys.

The increased power resulted in higher tensile strength of stainless steel wires, however, the other alloys did not safely obey this rule, especially the Beta-Ti alloy, which became brittle and showed low rupture strength. These factors may result in clinically undesirable effects, such as increased risks of corrosion, greater release of nickel, more biofilm accumulation and friction ${ }^{29}$.

The NiTi and Beta-Ti wires are widely used in orthodontics because of their high resilience and release of light and constant forces, and therefore, fewer changes of the orthodontic arch wires are needed ${ }^{11,30-31}$. However, other NiTi properties impose limitations with regard to orthodontic mechanics in which making "loops" and "omega" are not indicated ${ }^{32-33}$.

However, hooks, springs and different metal alloys, such as stainless steel, NiTi and Beta-Ti may be welded to NiTi1 and Beta-Ti wires ${ }^{30-31}$.

In this study, the surface roughness of $\mathrm{NiTi}^{23}$ was significantly higher than that of Beta-Ti wire, and the smoothest was stainless steel wire. This order was consistent with the experimental results of Bourauel et al..$^{34}$.

Observation by SEM of the chemical elements present in stainless steel and Beta-Ti wires alone and the weld bond of Steel $\times$ Beta-Ti at P50, showed that the melted and solidified materials present in the chemical components of the two alloys aggregate, which means change in the structural arrangement of these wires under high current (P50). As these changes may clinically interfere with the performance of wires ${ }^{22-23,35}$, use of P50 should be discouraged.

Some ligature combinations have shown good performance in the tensile test, but attention must be paid to their topography ${ }^{35}$. This must be taken into consideration, 
because traction results evaluated alone can stimulate the inappropriate clinical use of these alloys, since the altered topography ${ }^{35}$ of the wire after soldering can damage orthodontic mechanics ${ }^{29}$.

The combinations that most preserved the topographies were Steel $\times$ Steel, Steel $\times$ NiTi, NiTi $\times$ NiTi, NiTi $\times$ Beta-Ti and Beta-Ti $\times$ Beta-Ti at P30. The best tensile strength results were those obtained by Steel $\times$ Steel at P50 and Beta-Ti $\times$ Beta-Ti at P40 in which the tensile force observed would be clinically applicable, but the visibly altered topographies ${ }^{35}$ with evident welding points and highly melted wires at the intersection of the alloys would contra-indicate their clinical use.

The defects shown in the tests in the present study were equivalent to the clinical findings of complete ruptures without a real conjunction between two metal frameworks.
Therefore, welding changed the material attributes and the fact of missing wire quality has to be considered when planning orthodontic appliances.

\section{Conclusion}

Within the limits of this study, it may be concluded that the tensile strength of alloys combinations Steel $\times$ Beta-Ti was significantly affected by the current level at P50, certainly because of difference large between the melting temperature of Steel and Beta-Ti alloys. As regards the maintenance of the structure of wires and tensile strength assessed, the alloy combinations Steel $\times$ Steel, Steel $\times$ Beta-Ti and Beta-Ti $\times$ Beta-Ti at P30 and Steel $\times$ NiTi, NiTi $\times$ NiTi and NiTi $\times$ Beta-Ti at P40 are more appropriate for clinical use.

\section{References}

1. Santos RLS, Pithon MM, Nascimento LEAG, Martins FO, Romanos MTV, Nojima MC et al. Cytotoxicity of electric spot welding: an in vitro study. Dental Press Journal of Orthodontics. 2011; 16:57-63. http://dx.doi.org/10.1590/ S2176-94512011000300006

2. Kalimo K, Mattila L and Kautiainen H. Nickel allergy and orthodontic treatment. Journal of the European Academy of Dermatology and Venereology. 2004; 18:543-545. PMid:15324389. http://dx.doi.org/10.1111/ j.1468-3083.2004.01014.x

3. Vande Vannet B, Hanssens JL and Wehrbein H. The use of three-dimensional oral mucosa cell cultures to assess the toxicity of soldered and welded wires. European Journal of Orthodontics. 2007; 29:60-66. PMid:17290016. http://dx.doi. org/10.1093/ejo/cj1063

4. Sestini S, Notarantonio L, Cerboni B, Alessandrini C, Fimiani $\mathrm{M}$, Nannelli $\mathrm{P}$ et al. In vitro toxicity evaluation of silver soldering, electrical resistance, and laser welding of orthodontic wires. European Journal of Orthodontics. 2006; 28:567-572. PMid:17035485. http://dx.doi.org/10.1093/ejo/cj1048

5. Schultz JC, Connelly E, Glesne L and Warshaw EM. Cutaneous and oral eruption from oral exposure to nickel in dental braces. Dermatitis. 2004; 15:154-157. http://dx.doi. org/10.2310/6620.2004.04022

6. Saglam AM, Baysal V and Ceylan AM. Nickel and cobalt hypersensitivity reaction before and after orthodontic therapy in children. Journal of Contemporary Dental Practice. 2004; 5:79-90. PMid:15558093.

7. Oh KT and Kim KN. Ion release and cytotoxicity of stainless steel wires. European Journal of Orthodontics. 2005; 27:533540. PMid:16093259. http://dx.doi.org/10.1093/ejo/cji047

8. Azevedo CRF. Characterization of metallic piercings. Engineering Failure Analysis. 2003; 10:255-263. http://dx.doi. org/10.1016/S1350-6307(02)00079-1

9. Correr SL. Comparative study of the tensile strength of silver solders and super micro point, used in orthodontics. Journal of the Faculty of Dentistry of the UFP. 1997; 45:51-57.

10. Lopes MB, Correr Sobrinho L, Consani S, Sinhoreti MAC and Cangiani MB. Fatigue resistance between point electrical solder and silver solder utilized in orthodontics. Revista Dental Press de Ortodontia e Ortopedia Maxilar. 2000; 5(6):45-9.
11. Burstone CJ. Welding of TMA wire. Clinical applications. Journal of Clinical Orthodontics. 1987; 21:609-615. PMid:2895778.

12. Nelson KR, Burstone CJ and Goldberg AJ. Optimal welding of beta titanium orthodontic wires. American Journal of Orthodontics and Dentofacial Orthopedics. 1987; 92:213-219. http://dx.doi.org/10.1016/0889-5406(87)90414-8

13. Donovan MT, Lin JJ, Brantley WA and Conover JP. Weldability of beta titanium arch wires. American Journal of Orthodontics. 1984; 85:207-216. http://dx.doi. org/10.1016/0002-9416(84)90060-5

14. Angeline E. Corrosion resistance of solder joints for removable partial dentures. Dental Materials. 1989; 4:255-260. http:// dx.doi.org/10.1016/S0109-5641(88)80019-8

15. Morais LS, Guimarães GS and Elias CN. Release of metal ions by biomaterials. Dental Press Journal of Orthodontics. 2007; 12:48-53.

16. Cadosch D, Chan E and Gautschi OP. Bio-corrosion of stainless steel by osteoclasts-in vitro evidence. Journal of Orthopaedic Research. 2008; 70.

17. El Safty A, El Mahgoub K and Helal S. Zinc toxicity among galvanization workers in the iron and steel industry. Annals of the New York Academy of Sciences. 2008; 1140:256-262. PMid:18991923. http://dx.doi.org/10.1196/annals.1454.007

18. Grimsdottir MR, Gjerdet NR and Hensten-Pettersen A. Composition and in vitro corrosion of orthodontic appliances. American Journal of Orthodontics and Dentofacial Orthopedics. 1992; 101:525-532. http://dx.doi. org/10.1016/0889-5406(92)70127-V

19. Dua R and Nandlal B. A comparative evaluation of the tensile strength of silver soldered joints of stainless steel and cobalt chromium orthodontic wires with band material - an in vitro study. Journal of Indian Society of Pedodontics and Preventive Dentistry. 2004; 22:13-6. PMid:15255439.

20. Huang HH, Lin MC, Lin CC, Lin SC, Hsu CC, Chen FL, et al. Effects of welding pulse energy and fluoride ion on the cracking susceptibility and fatigue behavior of Nd:YAG laser-welded cast titanium joints. Dental Materials Journal .2006; 25:632-40. PMid:17076339. http://dx.doi.org/10.4012/ dmj. 25.632 
21. Sestini S, Notarantonio L, Cerboni B, Alessandrini C, Fimiani $\mathrm{M}$, Nannelli $\mathrm{P}$, et al. In vitro toxicity evaluation of silver soldering, electrical resistance, and laser welding of orthodontic wires. European Journal of Orthodontics. 2006; 28:567-72. PMid:17035485. http://dx.doi.org/10.1093/ejo/cj1048

22. Bourauel C, Scharold W, Jager A and Eliades T. Fatigue failure of as-received and retrieved NiTi orthodontic archwires. Dental Materials. 2008; 24:1095-1101. PMid:18289660. http://dx.doi. org/10.1016/j.dental.2007.12.007

23. Wichelhaus A, Geserick M, Hibst R and Sander FG. The effect of surface treatment and clinical use on friction in NiTi orthodontic wires. Dental Materials. 2005; 21:938-945. PMid:15923033. http://dx.doi.org/10.1016/j.dental.2004.11.011

24. Rocha R, Pinheiro AL and Villaverde AB. Flexural strength of pure Ti, Ni-Cr and Co-Cr alloys submitted to Nd:YAG laser or TIG welding. Brazilian Dental Journal. 2006; 17:20-3. http:// dx.doi.org/10.1590/S0103-64402006000100005

25. Watanabe I, Baba N, Chang J and Chiu Y. Nd:YAG laser penetration into cast titanium and gold alloy with different surface preparations. Journal of Oral Rehabilitation. 2006; 33:443-6. PMid:16671991. http://dx.doi. org/10.1111/j.1365-2842.2006.01512.x

26. Watanabe I and Topham DS. Laser welding of cast titanium and dental alloys using argon shielding. Journal of Prosthodontics. 2006; 15:102-7. PMid:16650010. http://dx.doi. org/10.1111/j.1532-849X.2006.00082.x

27. Suzuki Y, Ohkubo C, Abe M and Hosoi T. Titanium removable partial denture clasp repair using laser welding: a clinical report. Journal of Prosthetic Dentistry. 2004; 91:418-420. PMid:15153847. http://dx.doi.org/10.1016/j. prosdent.2004.01.019
28. Krishnan V and Kumar KJ. Mechanical properties and surface characteristics of three archwire alloys. Angle Orthodontist. 2004; 74:825-831. PMid:15673147.

29. Marques IS, Araujo AM, Gurgel JA and Normando D. Debris, roughness and friction of stainless steel archwires following clinical use. Angle Orthodontist. 2010; 80:521-527. PMid:20050747. http://dx.doi.org/10.2319/081109-457.1

30. Burstone CJ and Goldberg AJ. Beta titanium: a new orthodontic alloy. American Journal of Orthodontics. 1980; 77:121-132. http://dx.doi.org/10.1016/0002-9416(80)90001-9

31. Kapila S and Sachdeva R. Mechanical properties and clinical applications of orthodontic wires. American Journal of Orthodontics and Dentofacial Orthopedics. 1989; 96:100-109. http://dx.doi.org/10.1016/0889-5406(89)90251-5

32. Kusy RP and Greenberg AR. Effects of composition and cross section on the elastic properties of orthodontic wires. Angle Orthodontist. 1981; 51:325-341.

33. Kusy RP. On the use of nomograms to determine the elastic property ratios of orthodontic arch wires. American Journal of Orthodontics. 1983; 83:374-381. http://dx.doi. org/10.1016/0002-9416(83)90321-4

34. Bourauel C, Fries T, Drescher D and Plietsch R. Surface roughness of orthodontic wires via atomic force microscopy, laser specular reflectance, and profilometry. European Journal of Orthodontics. 1998; 20:79-92. http://dx.doi.org/10.1093/ ejo/20.1.79

35. Eliades T, Eliades G, Athanasiou AE and Bradley TG. Surface characterization of retrieved NiTi orthodontic archwires. European Journal of Orthodontics. 2000; 22:317-326. http:// dx.doi.org/10.1093/ejo/22.3.317 